\title{
EFFET OF COMBINATION OF HPMC AND CARBOPOL 934P ON THE PROPERTIES OF THE GASTRIC FOATING TABETS TIMOLOL MALATE
}

\author{
Charyulu Narayana R*, Girish S K, Amit B Patil. \\ Department of Pharmaceutics, Nitte Gulabi Shetty Memorial Institute of Pharmaceutical Sciences, Deralakatte, Mangalore, \\ INDIA-575 018 \\ *corresponding Author's Email: charyulun@yahoo.co.in
}

\begin{abstract}
:
The purpose of the present research was to evaluate the effect of carbopol 934P on gastroretentive drug delivery system. Floating tablet containing timolol maleate were prepared by direct compression method, using three grades of polymer HPMC [K15M, K4M, K100M] and carbopol 934P. Sodium bicarbonate and citric acid was incorporated as a gas-generating agent. The floating tablets were evaluated on the basis of pre-compression and post-compression characteristics. The pre-compression characteristics such as angle of repose, bulk density, tapered density and compressibility index showed satisfactory results for all the nine formulations. The results of post-compression such as weight variation, hardness, friability and drug content estimation showed that all the nine formulations complied with the official requirement of IP. The buoyancy lag time indicated that the formulation F1, F4 and F7 without carbopol 934P were less than $8 \mathrm{sec}$, where as formulation containing carbopol 934P had greater lag time. Formulation containing only HPMC grade polymers floated less than $8 \mathrm{~h}$ as compared to the formulation containing HPMC with carbopol 934P floated more than $12 \mathrm{~h}$. The in vitro dissolution studies indicated $94.2 \%$ drug release in $12 \mathrm{~h}$ by the formulations F2, F3, F5, F6, F8 and F9 containing different concentration of carbopol 934P with different grades of HPMC, when compared to $100 \%$ drug release within $9 \mathrm{~h}$ by the formulation F1, F4 and F7 containing only different grades of HPMC polymers. All formulation followed the Higuchi release model. The drug release from the tablets was sufficiently sustained and non-Fickian transport of the drug from tablets was confirmed. Hence it can be inferred that the inclusion of carbopol 934P can result in sustained drug delivery over $12 \mathrm{~h}$, enhances the gastric floating time and also increases buoyancy lag time.
\end{abstract}

Keywords: Timolol maleate, HPMC, carbopol 934P, Floating tablets, direct compression

\section{INTRODUCTION:}

Timolol maleate is a non-selective beta-adrenergic receptor blocker, prescribed in antihypertensive, antiarrhythmic and migraine. Timolol maleate is rapidly absorbed on oral administration with peak plasma concentration within 1-2 h. Plasma half-life of Timolol maleate is $2.5-4 \mathrm{~h}$. The oral bioavailability is $50 \%-60 \%$ due to extensive metabolism in liver ${ }^{1}$. Hence an attempt is been made to formulate a gastro retentive delivery system for timolol maleate that can not only avoid its metabolism in liver but also enhance the bioavailability. The advantage of floating drug delivery system is that it retains the drug in gastric environment and improvises sustain delivery of drugs that have an absorption window in a particular region of the gastrointestinal tract. Hence the aim is to formulate a timolol maleate gastric floating delivery system that will release the drug continuously at predetermined rate before it reaches the absorption window thus ensuring optimal bioavailability, improved patient compliance and reduced dose frequency ${ }^{2}$.

The gastric floating drug delivery systems have a bulk density less than gastric fluid and so remain buoyant in the stomach without affecting the gastric emptying rate for a prolonged period of time. This also results in an increased gastric retention time and better control of fluctuations of plasma drug concentration.

\section{MATERIALS AND METHODS:}

\section{MATERIALS:}

Timolol maleate was obtained as a gift sample from Ajanta Pharma, Mumbai. HPMC grade K4M, K15M, K100M and carbopol 934P was a gift sample from Merck Chemicals,
Germany. Sodium bicarbonate, citric acid, PVPK30, talc and magnesium stereate purchased from Reachem chemicals, Mumbai. All the chemicals used were of analytical grade.

\section{METHODS:}

\section{Formulation of timolol maleate floating tablet:}

The formulation was prepared according to the principle of effervescent technique, in which all the ingredients were weighed accurately as per the formulation Table 1. Initially a powder mixture of timolol maleate, HPMC grade K4M, K15M, K100M, carbopol 934P, Micro crystalline cellulose (MCC), sodium bicarbonate, citric acid and PVP K30 was prepared in a clear and dry mortar and pestle, then passed through sieve No \#80. Later magnesium stereate and talc were added as lubricant and glident respectively. An appropriate amount of the mixture was weighed and fed manually into the die of rotary single punch tablet machine using $8.5 \mathrm{~mm}$ punch to get tablets of average weight 330 $\mathrm{mg}$. The punched tablets were wrapped in aluminium foil and stored in an air tight pouch in a controlled environment of temperature and humidity until further studies $^{3}$.

\section{EVALUATION OF TIMOLOL MALEATE FLOATING TABLETS:}

Evaluation was performed to assess the pre-compression properties of the powder blend and post-compression properties of developed gastric floating tablet formulations. 
2.1. Pre-compression evaluation parameters of powder blends:

\section{Angle of repose:}

The angle of repose of powder blend was determined by the funnel method. Accurately weighed powder blends were filled in the funnel. The height of the funnel was adjusted in such a way that the tip of the funnel just touches the apex of the powder blend. The powder blend was allowed to flow through the funnel freely on to the surface. The diameter of the powder cone was measured and angle of repose was calculated using the following equation ${ }^{4}$.

$$
\begin{gathered}
\tan \theta=h / r \\
\theta=\tan ^{-1}(h / r)
\end{gathered}
$$

Where,

$\theta=$ angle of repose; $\mathrm{h}=$ height of the pile; $\mathrm{r}=$ radius of the cone made by powder blend

Table 1: Formulation of timolol maleate gastric floating tablet

\begin{tabular}{|c|c|c|c|c|c|c|c|c|c|}
\hline \multirow{3}{*}{ Ingredients } & \multicolumn{9}{|c|}{ Formulation code } \\
\cline { 2 - 11 } & $\begin{array}{c}\mathbf{F 1} \\
(\mathrm{mg})\end{array}$ & $\begin{array}{c}\mathbf{F 2} \\
(\mathrm{mg})\end{array}$ & $\begin{array}{c}\mathbf{F 3} \\
(\mathrm{mg})\end{array}$ & $\begin{array}{c}\mathbf{F 4} \\
(\mathrm{mg})\end{array}$ & $\begin{array}{c}\mathbf{F 5} \\
(\mathrm{mg})\end{array}$ & $\begin{array}{c}\mathbf{F 6} \\
(\mathrm{mg})\end{array}$ & $\begin{array}{c}\mathbf{F 7} \\
(\mathrm{mg})\end{array}$ & $\begin{array}{c}\text { F8 } \\
(\mathrm{mg})\end{array}$ & $\begin{array}{c}\mathbf{F 9} \\
(\mathrm{mg})\end{array}$ \\
\hline HPMC K15M & 150 & 120 & 120 & - & - & - & - & - & - \\
\hline HPMC K4M & - & - & - & 150 & 120 & 120 & - & - & - \\
\hline HPMC K100M & - & - & - & - & - & - & 150 & 120 & 120 \\
\hline Carbopol 934P & - & 20 & 30 & - & 20 & 30 & - & 20 & 30 \\
\hline Timolol maleate & 25 & 25 & 25 & 25 & 25 & 25 & 25 & 25 & 25 \\
\hline $\begin{array}{c}\text { Sodium } \\
\text { bicarbonate }\end{array}$ & 60 & 60 & 60 & 60 & 60 & 60 & 60 & 60 & 60 \\
\hline Citric acid & 20 & 20 & 20 & 20 & 20 & 20 & 20 & 20 & 20 \\
\hline MCC & 60 & 70 & 60 & 60 & 70 & 60 & 60 & 70 & 60 \\
\hline PVP K30 & 10 & 10 & 10 & 10 & 10 & 10 & 10 & 10 & 10 \\
\hline Talc & 2 & 2 & 2 & 2 & 2 & 2 & 2 & 2 & 2 \\
\hline Magnesium \\
stearate & 3 & 3 & 3 & 3 & 3 & 3 & 3 & 3 & 3 \\
\hline Total & 330 & 330 & 330 & 330 & 330 & 330 & 330 & 330 & 330 \\
\hline
\end{tabular}

\section{Bulk density:}

Both loose bulk density and tapped bulk density were determined. A quantity accurately equal to $10 \mathrm{~g}$ of powder from each formulation was introduced into a $10 \mathrm{ml}$ measuring cylinder. Initial volume was observed, the cylinder was allowed to tap. The tapping was continued until no further change in volume was noted. Bulk density was calculated by using formula ${ }^{4}$.

\section{Bulk density $=M / V_{0}$}

Where,

$\mathrm{M}=$ mass of powder. $\mathrm{V}_{0}=$ bulk volume of the powder.

$$
\text { Tapped density }=\mathrm{M} / \mathrm{Vt}
$$

Where,

$\mathrm{M}=$ mass of powder, $\mathrm{Vt}=$ tapped volume of the powder.

\section{Compressibility Index (Carr's consolidation Index):}

Another indirect method of measuring flow from bulk densities was developed by Carr. The percentage compressibility of a powder is a direct measure of the potential powder arch or bridge strength and stability. It is calculated according to the following equation ${ }^{4}$.

Carr's index $(\%)=\frac{\text { (Tapped densit }- \text { Bulk density) }}{\text { Tapped density }} \times 100$

2.2. Post-compression evaluation parameters of timolol maleate gastric floating tablet

Thickness test:
Thickness test was performed by measuring the thickness of the tablet at different positions using a standard calibrated screw gauge meter. The thickness was expressed in $\mathrm{mm}$. Three tablets from each formulation were selected randomly ${ }^{5}$.

Hardness test:

The hardness of the tablets was determined using Pfizer hardness tester. It is expressed in $\mathrm{kg} / \mathrm{cm}^{2}$. Three tablets from each formulation were selected randomly ${ }^{5}$.

Friability:

Roche friabilator was used for testing the friability of the tablets. Twenty tablets were weighed accurately and placed in the tumbling apparatus that revolves at $25 \mathrm{rpm}$. After $4 \mathrm{~min}$ the tablets were weighed and the percentage loss in tablet weight was determined ${ }^{5}$.

\section{Weight variation test:}

Twenty tablets were weighed individually and the average weight was determined. Then percentage deviation from the average weight was calculated ${ }^{5}$.

\section{Drug content estimation:}

Randomly selected ten tablets were weighed and powdered in a mortar and pestle. Powder weighing equivalent to 330 mg of timolol maleate was accurately weighed and transferred into a $100 \mathrm{ml}$ volumetric flask and dissolved in $0.1 \mathrm{~N} \mathrm{HCl}, \mathrm{pH}$ 1.2. Subsequently the solution from volumetric flask was filtered and suitable dilutions were made. These aliquots were analyzed at $275 \mathrm{~nm}$ using UVVisible spectrophotometer. The drug content of each sample was estimated from standard curve of clarithromycin using $0.1 \mathrm{~N} \mathrm{HCl}, \mathrm{pH} 1.2^{7}$. 


\section{Swelling index:}

Swelling property of tablet was determined by placing it in the dissolution test apparatus, in $900 \mathrm{ml}$ of $0.1 \mathrm{~N} \mathrm{HCL}$ at $37 \pm 2{ }^{\circ} \mathrm{C}$. The weight and volume reached by the matrix tablets over time was determined by withdrawing the tablets periodically from dissolution medium. The tablets were weighed on an analytical balance after slight blotting with tissue paper to remove the excess liquid. The volume of the tablets was obtained by measuring the thickness and diameter, considering a right circular cylinder form. The determined weight and volume were used to calculate the tablet density over the dissolution study. Swelling characteristics were expressed in terms of percentage water uptake (WU \%) or swelling index according to the equation ${ }^{8}$.

$$
\text { Swelling index }(W U \%)=\frac{W f-W i}{W i} \times 100
$$

Where,

$\mathrm{Wi}=$ initial weight of tablet, $\mathrm{Wf}=$ final weight of tablet

\section{The buoyancy lag time and the total floating time:}

Buoyancy or floating behavior studies was carried out in a USP Dissolution Testing Apparatus II (Paddle type) at paddle speed $50 \mathrm{rpm}$ in $900 \mathrm{ml} 0.1 \mathrm{~N} \mathrm{HCl}$ at $37 \pm 0.2{ }^{\circ} \mathrm{C}$ for $24 \mathrm{~h}$ to mimic in vivo conditions. For determining the optimized buoyancy lag time and total floating time of the delivery system, various formulations prepared according to table 1 were studied. The time interval between the introduction of the tablet into the dissolution medium and its buoyancy to the top of dissolution medium was taken as floating lag time, the duration of system floatation and also the relative matrix integrity was observed visually ${ }^{7}$.

\section{In vitro drug release}

The in vitro release rate of timolol maleate from floating tablets was determined using USP dissolution testing apparatus II (paddle type). The test was performed using $900 \mathrm{ml}$ of $0.1 \mathrm{~N} \mathrm{HCl}$ at $37 \pm 0.5{ }^{\circ} \mathrm{C}$ and $50 \mathrm{rpm}$ for study. The amount of drug released over time was determined by withdrawing samples at various determined time intervals for $24 \mathrm{hrs}$ and were replaced with fresh dissolution medium. The aliquots were filtered through Whattman filter paper Grade-1and concentration of drug was obtained by measuring the absorbance at $275 \mathrm{~nm}$ using UV-Visible spectrophotometer ${ }^{8}$.

\section{RESULTS:}

Pre-compression evaluation parameters of powder blends:

The pre-compression parameters such as angle of repose, bulk density, tapered density and compressibility index were evaluated. The results of all the pre compression parameters were found to comply with the specification of IP. The results are displayed in Table 2.

Post-compression evaluation parameters of timolol maleate gastric floating tablet:

All the formulations subjected for post-compression characterization of morphological properties such as thickness, hardness, weight variation and friability test showed satisfactory results which were within the limits for all the formulation. The results of these tests are reported in Table 3 .

Table 2: Pre-compression evaluation parameters of gastric floating tablets

\begin{tabular}{|c|c|c|c|c|}
\hline Formulation code & $\begin{array}{c}\text { Angle of repose* } \\
\mathbf{\pm} \mathbf{S D}(\boldsymbol{\theta})\end{array}$ & $\begin{array}{c}\text { Bulk density* } \\
\mathbf{\pm} \mathbf{S D}(\mathbf{g} / \mathbf{m l})\end{array}$ & $\begin{array}{c}\text { Tapped density* } \\
\mathbf{\pm} \text { SD }(\mathbf{g} / \mathbf{m l})\end{array}$ & $\begin{array}{c}\text { Compressibility index* } \pm \\
\text { SD }(\boldsymbol{\%})\end{array}$ \\
\hline F1 & $18.24 \pm 0.11$ & $0.464 \pm 0.08$ & $0.542 \pm 0.09$ & $15.12 \pm 0.09$ \\
\hline F2 & $19.71 \pm 0.09$ & $0.479 \pm 0.06$ & $0.512 \pm 0.08$ & $18.94 \pm 0.09$ \\
\hline F3 & $20.14 \pm 0.09$ & $0.462 \pm 0.05$ & $0.571 \pm 0.07$ & $18.91 \pm 0.10$ \\
\hline F4 & $18.96 \pm 0.14$ & $0.483 \pm 0.10$ & $0.563 \pm 0.09$ & $14.20 \pm 0.12$ \\
\hline F5 & $20.04 \pm 0.21$ & $0.492 \pm 0.11$ & $0.593 \pm 0.01$ & $17.03 \pm 0.12$ \\
\hline F6 & $20.62 \pm 0.11$ & $0.487 \pm 0.05$ & $0.581 \pm 0.01$ & $16.17 \pm 0.11$ \\
\hline F7 & $19.13 \pm 0.13$ & $0.493 \pm 0.09$ & $0.577 \pm 0.09$ & $14.55 \pm 0.05$ \\
\hline F8 & $20.45 \pm 0.09$ & $0.461 \pm 0.08$ & $0.542 \pm 0.09$ & $15.12 \pm 0.04$ \\
\hline F9 & $22.50 \pm 0.09$ & $0.487 \pm 0.07$ & $0.581 \pm 0.10$ & $16.17 \pm 0.05$ \\
\hline
\end{tabular}

Table 3: Post-compression parameters of gastric floating tablets

\begin{tabular}{|c|c|c|c|c|}
\hline Formulation code & $\begin{array}{c}\text { Average thickness* } \\
\mathbf{\pm} \text { SD }(\mathbf{m m})\end{array}$ & $\begin{array}{c}\text { Hardness* } \\
\mathbf{\pm} \text { SD (kg/cm2) }\end{array}$ & $\begin{array}{c}\text { Weight variation* } \\
\mathbf{\pm} \text { SD (mg) }\end{array}$ & Percentage friability \\
\hline F1 & $4.4 \pm 0.001$ & $5.1 \pm 0.2$ & $328 \pm 2.43$ & $0.48 \%$ \\
\hline F2 & $4.5 \pm 0.004$ & $5.4 \pm 0.8$ & $327 \pm 2.40$ & $0.39 \%$ \\
\hline F3 & $4.6 \pm 0.003$ & $5.2 \pm 0.9$ & $330 \pm 2.71$ & $0.21 \%$ \\
\hline F4 & $4.8 \pm 0.001$ & $5.3 \pm 0.8$ & $332 \pm 2.41$ & $0.28 \%$ \\
\hline F5 & $4.5 \pm 0.002$ & $5.1 \pm 0.5$ & $328 \pm 2.74$ & $0.34 \%$ \\
\hline F6 & $4.6 \pm 0.003$ & $5.2 \pm 0.6$ & $329 \pm 2.49$ & $0.42 \%$ \\
\hline F7 & $4.4 \pm 0.002$ & $5.4 \pm 0.7$ & $329 \pm 2.33$ & $0.19 \%$ \\
\hline F9 & $4.3 \pm 0.005$ & $5.3 \pm 0.9$ & $328 \pm 2.98$ & $0.35 \%$ \\
\hline
\end{tabular}

*Each reading is an average of 6 determinants

Buoyancy studies: 
F1, F4 and F7 showed good buoyancy lag time less than $10 \mathrm{sec}$, but it did not float for more than $9 \mathrm{~h}$. The batch containing HPMC polymer with Carbopol 934P in concentration of $20 \mathrm{mg}$ and $30 \mathrm{mg}$ such as F2, F3, F5, F6, F8 and F9 showed poor lag time less than 2 mins but exhibited good total floating time of more than $12 \mathrm{~h}$. The results are reported in Table 4.

\section{Drug content:}

The drug content varied from $91.20 \pm 0.44 \%$ to $100.01 \pm$ $0.04 \%$ which was within the required limits of $\pm 2 \%$ according to IP. The results of the tests are given in Table 4.

Table 4: Buoyancy lag time and total floating time of gastric floating tablets

\begin{tabular}{|c|c|c|c|}
\hline Formulation code & Buoyancy Lag time* $\mathbf{E D}(\mathbf{s e c})$ & Total floating time $(\mathbf{h})$ & Percentage Drug content* \pm SD \\
\hline F1 & $8 \pm 1.2$ & $\leq 9$ & $97.14 \pm 0.15$ \\
\hline F2 & $48 \pm 2.8$ & $>12$ & $96.53 \pm 0.23$ \\
\hline F3 & $67 \pm 3.3$ & $>12$ & $93.72 \pm 0.12$ \\
\hline F4 & $6 \pm 2.3$ & $\leq 9$ & $97.95 \pm 0.22$ \\
\hline F5 & $51 \pm 4.5$ & $>12$ & $95.88 \pm 0.34$ \\
\hline F6 & $72 \pm 6.6$ & $>12$ & $100.01 \pm 0.4$ \\
\hline F7 & $7 \pm 3.1$ & $>12$ & $97.91 \pm 0.23$ \\
\hline F8 & $40 \pm 2.7$ & $>12$ & $92.40 \pm 0.17$ \\
\hline
\end{tabular}

\section{Swelling index studies:}

The swelling index studies performed on all the formulations showed that the swelling index of HPMC $\mathrm{K} 15 \mathrm{M}, \mathrm{K} 4 \mathrm{M}$ and K100M was found to be 184.3, 164.3 and
278.8 at the end of $8 \mathrm{~h}$ respectively. Whereas formulation F2, F3, F5, F6, F8 and F9 containing HPMC K15M, K4M and K100M with 20 and $30 \mathrm{mg}$ of Carbopol 934P was $245.6,261.7,228.7,258.3,296.3$ and 311.8 respectively at the end of $9 \mathrm{~h}$. The results are shown in Table 5 .

Table 5: Swelling index studies

\begin{tabular}{|c|c|c|c|c|c|c|c|c|c|}
\hline Time (h) & F1* & F2* & F3* & F4* & F5* & F6* & F7* & F8* & F9* \\
\hline 0.5 & $\begin{array}{l}32.81 \\
\pm 0.08 \\
\end{array}$ & $\begin{array}{l}51.23 \\
\pm 0.19 \\
\end{array}$ & $\begin{array}{r}63.71 \\
\pm 0.09 \\
\end{array}$ & $\begin{array}{l}31.85 \\
\pm 0.06 \\
\end{array}$ & $\begin{array}{l}45.22 \\
\pm 0.02 \\
\end{array}$ & $\begin{array}{l}56.35 \\
\pm 0.05 \\
\end{array}$ & $\begin{array}{l}64.13 \\
\pm 0.15 \\
\end{array}$ & $\begin{array}{l}78.38 \\
\pm 0.11 \\
\end{array}$ & $\begin{array}{l}80.19 \\
\pm 0.19 \\
\end{array}$ \\
\hline 1 & $\begin{array}{r}48.43 \\
\pm 0.20\end{array}$ & $\begin{array}{l}75.32 \\
\pm 0.03\end{array}$ & $\begin{array}{l}81.42 \\
\pm 0.03\end{array}$ & $\begin{array}{l}40.64 \\
\pm 0.17\end{array}$ & $\begin{array}{l}60.34 \\
\pm 0.14\end{array}$ & $\begin{array}{l}78.65 \\
\pm 0.13\end{array}$ & $\begin{array}{c}89.3 \\
\pm 0.01\end{array}$ & $\begin{array}{l}110.4 \\
\pm 0.05\end{array}$ & $\begin{array}{l}116.3 \\
\pm 0.29\end{array}$ \\
\hline 2 & $\begin{array}{l}64.52 \\
\pm 0.01\end{array}$ & $\begin{array}{l}108.8 \\
\pm 0.12\end{array}$ & $\begin{array}{l}117.1 \\
\pm 0.19\end{array}$ & $\begin{array}{l}60.71 \\
\pm 0.09\end{array}$ & $\begin{array}{l}89.65 \\
\pm 0.12\end{array}$ & $\begin{array}{l}110.8 \\
\pm 0.09\end{array}$ & $\begin{array}{l}119.4 \\
\pm 0.06\end{array}$ & $\begin{array}{l}134.5 \\
\pm 0.08\end{array}$ & $\begin{array}{l}143.2 \\
\pm 0.06\end{array}$ \\
\hline 3 & $\begin{array}{r}101.5 \\
\pm 0.15\end{array}$ & $\begin{array}{l}158.3 \\
\pm 0.17\end{array}$ & $\begin{array}{l}176.1 \\
\pm 0.14\end{array}$ & $\begin{array}{l}94.31 \\
\pm 0.07\end{array}$ & $\begin{array}{l}108.9 \\
\pm 0.13\end{array}$ & $\begin{array}{l}154.9 \\
\pm 0.04\end{array}$ & $\begin{array}{l}169.1 \\
\pm 0.16\end{array}$ & $\begin{array}{l}166.6 \\
\pm 0.14\end{array}$ & $\begin{array}{l}176.8 \\
\pm 0.07\end{array}$ \\
\hline 4 & $\begin{array}{r}143.7 \\
\pm 0.22\end{array}$ & $\begin{array}{l}175.3 \\
\pm 0.10\end{array}$ & $\begin{array}{l}201.3 \\
\pm 0.15\end{array}$ & $\begin{array}{l}132.1 \\
\pm 0.05\end{array}$ & $\begin{array}{l}148.1 \\
\pm 0.14\end{array}$ & $\begin{array}{l}188.1 \\
\pm 0.03\end{array}$ & $\begin{array}{l}184.2 \\
\pm 0.11\end{array}$ & $\begin{array}{l}189.7 \\
\pm 0.15\end{array}$ & $\begin{array}{l}199.1 \\
\pm 0.14\end{array}$ \\
\hline 5 & $\begin{array}{r}158.6 \\
\pm 0.19\end{array}$ & $\begin{array}{l}195.1 \\
\pm 0.11\end{array}$ & $\begin{array}{l}223.6 \\
\pm 0.15\end{array}$ & $\begin{array}{l}141.7 \\
\pm 0.01\end{array}$ & $\begin{array}{l}174.4 \\
\pm 0.12\end{array}$ & $\begin{array}{l}213.3 \\
\pm 0.08\end{array}$ & $\begin{array}{l}213.4 \\
\pm 0.19\end{array}$ & $\begin{array}{l}217.9 \\
\pm 0.13\end{array}$ & $\begin{array}{l}227.3 \\
\pm 0.13\end{array}$ \\
\hline 6 & $\begin{array}{l}169.2 \\
\pm 0.16\end{array}$ & $\begin{array}{l}220.3 \\
\pm 0.09\end{array}$ & $\begin{array}{l}246.7 \\
\pm 0.11\end{array}$ & $\begin{array}{l}154.8 \\
\pm 0.07\end{array}$ & $\begin{array}{l}193.3 \\
\pm 0.17\end{array}$ & $\begin{array}{l}236.4 \\
\pm 0.11\end{array}$ & $\begin{array}{l}246.3 \\
\pm 0.13\end{array}$ & $\begin{array}{l}234.1 \\
\pm 0.19\end{array}$ & $\begin{array}{l}249.2 \\
\pm 0.15\end{array}$ \\
\hline 7 & $\begin{array}{r}175.5 \\
\pm 0.17\end{array}$ & $\begin{array}{l}236.4 \\
\pm 0.05\end{array}$ & $\begin{array}{l}254.7 \\
\pm 0.14\end{array}$ & $\begin{array}{l}158.1 \\
\pm 0.14\end{array}$ & $\begin{array}{l}210.1 \\
\pm 0.05\end{array}$ & $\begin{array}{l}247.2 \\
\pm 0.14\end{array}$ & $\begin{array}{l}269.7 \\
\pm 0.12\end{array}$ & $\begin{array}{c}256 \\
\pm 0.11\end{array}$ & $\begin{array}{l}267.5 \\
\pm 0.19\end{array}$ \\
\hline 8 & $\begin{array}{r}184.3 \\
\pm 0.16\end{array}$ & $\begin{array}{l}241.7 \\
\pm 0.06\end{array}$ & $\begin{array}{l}258.9 \\
\pm 0.01\end{array}$ & $\begin{array}{l}164.3 \\
\pm 0.11\end{array}$ & $\begin{array}{l}221.6 \\
\pm 0.08\end{array}$ & $\begin{array}{l}253.1 \\
\pm 0.18\end{array}$ & $\begin{array}{l}278.8 \\
\pm 0.09\end{array}$ & $\begin{array}{l}279.1 \\
\pm 0.19\end{array}$ & $\begin{array}{l}284.5 \\
\pm 0.12\end{array}$ \\
\hline 9 & & $\begin{array}{l}245.6 \\
\pm 0.09\end{array}$ & $\begin{array}{l}261.7 \\
\pm 0.02\end{array}$ & & $\begin{array}{l}228.7 \\
\pm 0.02\end{array}$ & $\begin{array}{l}258.3 \\
\pm 0.16\end{array}$ & & $\begin{array}{l}296.3 \\
\pm 0.09\end{array}$ & $\begin{array}{l}311.8 \\
\pm 0.07\end{array}$ \\
\hline
\end{tabular}

\section{In vitro drug release:}

The in vitro drug release data for Formulation F1, F4 and F7 was found to be above 95\% drug release in $8 \mathrm{~h}$ containing only different grades of HPMC and $90-95 \%$ in $12 \mathrm{~h}$ for formulation F2, F3, F5, F6, F8 and F9 containing different grades of HPMC with carbopol 934P. The results are given in fig. 1 .

\section{Drug Release Kinetics:}

The various drug release kinetic models were studied for the value of correlation coefficient. The best linearity was found in Higuchi's plot as its linear regression is nearer to ' 1 ' indicating the release of drug from matrix as a square root of time. The ' $n$ ' values which characterizes diffusion release mechanism by Krospeyer peppas model was found to be in the range of 0.45 to 0.63 . (Table 6). 


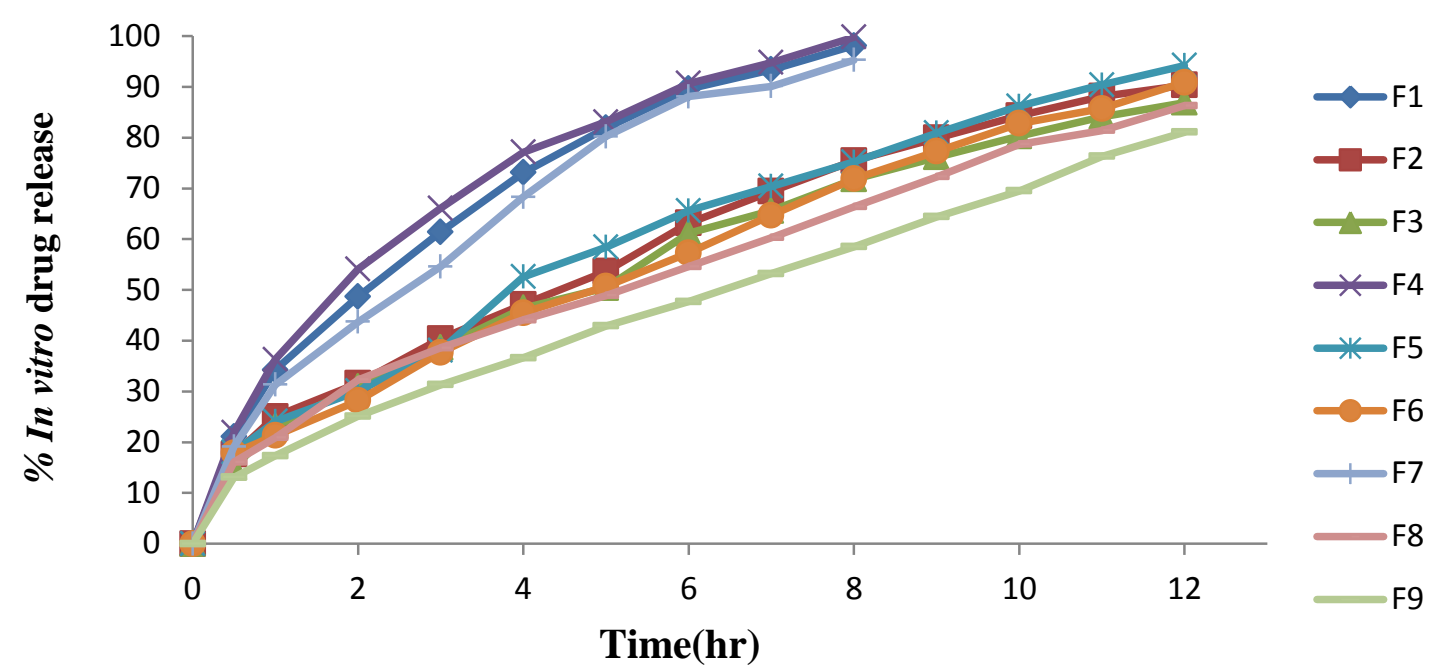

Figure 1: In vitro drug release profile of timolol maleate gastric floating tablet.

Table 6: Drug Release kinetics profile of dissolution studies

\begin{tabular}{|c|c|c|c|c|}
\hline \multirow{2}{*}{ Formulation code } & \multicolumn{4}{|c|}{ Kinetic models } \\
\cline { 2 - 5 } & Zero order & First order & Higuchi order & Korsmeyer-peppas order \\
\cline { 2 - 5 } & $\mathrm{y}=11.393 \mathrm{x}+18.559$ & $\mathrm{y}=-0.0859 \mathrm{x}+1.4951$ & $\mathrm{y}=36.326 \mathrm{x}-1.6586$ & $\mathrm{y}=0.9776 \mathrm{x}+1.1816$ \\
$\mathrm{~F} 1$ & $\mathrm{R}^{2}=0.9212$ & $\mathrm{R}^{2}=0.138$ & $\mathrm{R}^{2}=0.9962$ & $\mathrm{R}^{2}=0.4513$ \\
\hline \multirow{2}{*}{$\mathrm{F} 2$} & $\mathrm{y}=8.4222 \mathrm{x}+11.599$ & $\mathrm{y}=-0.0272 \mathrm{x}+1.5656$ & $\mathrm{y}=26.179 \mathrm{x}-2.1993$ & $\mathrm{y}=0.9056 \mathrm{x}+1.0774$ \\
& $\mathrm{R}^{2}=0.9613$ & $\mathrm{R}^{2}=0.0467$ & $\mathrm{R}^{2}=0.988$ & $\mathrm{R}^{2}=0.4586$ \\
\hline \multirow{2}{*}{$\mathrm{F} 3$} & $\mathrm{y}=6.6968 \mathrm{x}+14.636$ & $\mathrm{y}=-0.0163 \mathrm{x}+1.5511$ & $\mathrm{y}=26.084 \mathrm{x}-3.6259$ & $\mathrm{y}=0.9264 \mathrm{x}+1.0459$ \\
& $\mathrm{R}^{2}=0.9557$ & $\mathrm{R}^{2}=0.0178$ & $\mathrm{R}^{2}=0.9939$ & $\mathrm{R}^{2}=0.4851$ \\
\hline \multirow{2}{*}{ F4 } & $\mathrm{y}=11.286 \mathrm{x}+21.074$ & $\mathrm{y}=-0.1114 \mathrm{x}+1.5182$ & $\mathrm{y}=36.432 \mathrm{x}+0.2845$ & $\mathrm{y}=0.9662 \mathrm{x}+1.203$ \\
& $\mathrm{R}^{2}=0.8956$ & $\mathrm{R}^{2}=0.1968$ & $\mathrm{R}^{2}=0.9928$ & $\mathrm{R}^{2}=0.4362$ \\
\hline \multirow{2}{*}{ F5 } & $\mathrm{y}=7.2149 \mathrm{x}+15.559$ & $\mathrm{y}=-0.0377 \mathrm{x}+1.5894$ & $\mathrm{y}=28.07 \mathrm{x}-4.0487$ & $\mathrm{y}=0.874 \mathrm{x}+1.0839$ \\
& $\mathrm{R}^{2}=0.9552$ & $\mathrm{R}^{2}=0.0827$ & $\mathrm{R}^{2}=0.9912$ & $\mathrm{R}^{2}=0.5636$ \\
\hline \multirow{2}{*}{$\mathrm{F} 6$} & $\mathrm{y}=6.9517 \mathrm{x}+13.299$ & $\mathrm{y}=-0.024 \mathrm{x}+1.5793$ & $\mathrm{y}=26.746 \mathrm{x}-4.9501$ & $\mathrm{y}=0.866 \mathrm{x}+1.0599$ \\
& $\mathrm{R}^{2}=0.9719$ & $\mathrm{R}^{2}=0.0361$ & $\mathrm{R}^{2}=0.9863$ & $\mathrm{R}^{2}=0.5695$ \\
\hline \multirow{2}{*}{ F7 } & $\mathrm{y}=11.241 \mathrm{x}+15.559$ & $\mathrm{y}=-0.0514 \mathrm{x}+1.4665$ & $\mathrm{y}=35.383 \mathrm{x}-3.6081$ & $\mathrm{y}=0.9914 \mathrm{x}+1.1477$ \\
& $\mathrm{R}^{2}=0.9425$ & $\mathrm{R}^{2}=0.0577$ & $\mathrm{R}^{2}=0.9933$ & $\mathrm{R}^{2}=0.4727$ \\
\hline \multirow{2}{*}{ F8 } & $\mathrm{y}=6.4249 \mathrm{x}+14.039$ & $\mathrm{y}=-0.011 \mathrm{x}+1.5513$ & $\mathrm{y}=24.886 \mathrm{x}-3.1854$ & $\mathrm{y}=0.8518 \mathrm{x}+1.0543$ \\
& $\mathrm{R}^{2}=0.964$ & $\mathrm{R}^{2}=0.0081$ & $\mathrm{R}^{2}=0.9915$ & $\mathrm{R}^{2}=0.5656$ \\
\hline \multirow{2}{*}{ F9 } & $\mathrm{y}=6.1067 \mathrm{x}+9.8305$ & $\mathrm{y}=-0.0535 \mathrm{x}+2.0016$ & $\mathrm{y}=23.276 \mathrm{x}-5.7325$ & $\mathrm{y}=0.8761 \mathrm{x}+0.9799$ \\
& $\mathrm{R}^{2}=0.9827$ & $\mathrm{R}^{2}=0.965$ & $\mathrm{R}^{2}=0.9787$ & $\mathrm{R}^{2}=0.6137$ \\
\hline
\end{tabular}

\section{Stability studies}

Accelerated stability studies were conducted to observe any change in colour, appearance and drug content test at room temperature and oven temperature $\left(40 \pm 2{ }^{\circ} \mathrm{C}\right)$ buoyancy lag time for a period of eight weeks. There was no significant colour and drug content change observed at the end of eight weeks in all the formulations.

\section{DISCUSSION:}

The aim of the present research was to formulate gastric floating tablets of timolol maleate by using three different grades of HPMC polymer (K15M, K4M and K100M) alone and then by combining these HPMC polymers individually with two different concentration (6\% and 9\%) carbopol 934P and study the effect of carbopol 934P on the different properties of the gastric floating tablet. Hence three formulations of each grade of HPMC polymer with and without carbopol $934 \mathrm{P}$ were prepared yielding a total of nine formulations.
The characterization was carried out in two stages i.e. precompression and post-compression evaluation parameters. The pre-compression evaluation parameters comprised of powder properties like angle of repose, bulk density, tapered density and compressibility index which was done to ensure that the mixture of powder possessed the necessary characteristics to undergo compression. The results of the pre-compression parameters showed that the powder mixture of all the nine formulations were well within the limits as prescribed in IP, indicating its suitability to undergo compression. The post-compression parameters were carried out in two stages, namely morphological and physico-chemical evaluation. The postcompression morphological characteristics included thickness, hardness, weight variation and friability test which were carried out under standard controlled environment. According to the results of Table 3, it can be interpreted that all the nine formulations showed satisfactory results which were within the limits prescribed 
by IP. The post-compression physico-chemical characteristics included buoyancy studies, swelling time, in vitro drug release, drug release kinetics and stability studies. The buoyancy studies reviled that formulation F1, F4 and F7 which contained HPMC K15M, K4M and K100M showed buoyancy lag time less than $10 \mathrm{sec}$ and total floating time of $\leq 9 \mathrm{~h}$ when compared to formulations F2, F3, F5, F6, F8 and F9 with buoyancy lag time less than $2 \mathrm{~min}$ and total floating time more than $12 \mathrm{~h}$. Increased buoyancy lag time and satisfactory total floating can be attributed to the presence of carbopol 934P in different concentration.

Optimum swelling index was seen for tablets of batch F8 containing $120 \mathrm{mg}$ of HPMC K100M and $20 \mathrm{mg}$ of Carbopol 934P as compared to other formulations. The nominal viscosity of F8 was found to be more than $1,04,120 \mathrm{cps}$. Thus, the viscosity of the polymer had major influence on swelling process, matrix integrity, as well as floating capability, hence from the results of Table 5 it can be concluded that linear relationship exists between swelling process and viscosity of polymer. Thus swelling index showed the following order HPMC K100M > HPMC $\mathrm{K} 15 \mathrm{M}>\mathrm{HPMC}$ K4M i.e. F7 > F1 > F4; with addition of carbopol 934P there was further increase in the swelling property but the order remained same i.e. F9 > F8 > F3 > F6 > F2 > F5.

The formulation F1, F4 F7 containing polymer HPMC $\mathrm{K} 15 \mathrm{M}, \mathrm{K} 4 \mathrm{M}$ and $\mathrm{K} 100 \mathrm{M}$ in $30 \%$ concentration floated for $\leq 9 \mathrm{~h}$ but later it get disintegrated. The formulation containing Carbopol 934P with concentration of $6 \%$ and $9 \%$ are F2, F3, F5, F6, F8, F9 shown total floating time more than $14 \mathrm{~h}$ without any disintegration or erosion. A perusal to figure 1, it can be concluded that combination of anionic carbopol 934P and non ionic HPMC polymer produce synergistic inclusion in viscosity which could be due to $\mathrm{H}$-bonding between carboxyl group of carbopol and $\mathrm{OH}$ group of HPMC that lead to stronger cross linking between two polymer and retarding the drug release.

The in vitro drug release data for Formulation F1, F4 and F7 was found to be above $95 \%$ in $8 \mathrm{~h}$. Improvement in the drug release was seen by including 6\% carbopol 934P in Formulation F2, F5 and F8 showing in vitro drug release between $90-95 \%$ in $12 \mathrm{~h}$. Carbopol acted as drug release retarding agent, by swelling and forming colloidal mucilage that may help resist disintegration of gastric floating tablet in gastric fluid. By increasing the concentration of carbopol $934 \mathrm{P}$ to $9 \%$ as in case of F3, F6 and F9 formulations, the drug release was less than $90 \%$ in $12 \mathrm{~h}$ which proved to be optimum concentration of polymer and gas generating agent. Among all the formulations prepared, formulation F5 exhibit optimum drug release $94.2 \%$ in $12 \mathrm{~h}$ with buoyancy lag time of 51 sec.

The drug release kinetic data showed best linearity in Higuchi's plot as its linear regression was nearer to ' 1 ' indicating the release of drug from matrix as a square root of time. This model is widely used when the release mechanism is not well known or when more than one type of release phenomenon was involved. The ' $n$ ' values can be used to characterize diffusion release mechanism by Krospeyer peppas model. The ' $\mathrm{n}$ ' value for all formulations was found to be in the range of 0.45 to 0.63 which indicates that the release approximates non-fickian diffusion mechanism. Hence combination of diffusion and erosion can be considered as mechanism of drug release from the formulations.

Accelerated stability studies showed that there was no significant change in colour, appearance and/or drug content at room temperature and oven temperature. And also no changes in buoyancy lag time after a period of eight weeks in all the 9 formulations. This indicated good stability of the prepared formulations.

\section{CONCLUSION}

The effervescent-based floating drug delivery was a promising approach to achieve in vitro buoyancy. The addition of gel-forming polymer HPMC (K100, K15M, $\mathrm{K} 4 \mathrm{M}$ ) with carbopol 934P and gas-generating agent sodium bicarbonate along with citric acid was essential to achieve in vitro buoyancy. Carbopol 934P has given extra adhesion property and helped to maintain the integrity of the floating tablet. The drug release from the timolol maleate floating tablets was sufficiently sustained and nonFickian transport of the drug from tablets was confirmed.

\section{ACKNOLEDGEMENT:}

The authors express their sincere gratitude to the NITTE University and the Principle, NGSM Institute of Pharmaceutical Sciences, Mangalore, for providing necessary facility to carry out the research work.

\section{CONFLICTS OF INTEREST:}

The authors do not have any conflicts of interest.

6. Libermann HA, Lachman L, Schwartz JB. Pharmaceutical dosage forms: Tablets. Vol 1. New York: Marcel Dekker Inc; 1989. P. 48-9.

7. The United States Pharmacopoeia and The National Formulary, United States Pharmacopoeia Convention INC Rockville; 2003. P. 89-99.

8. Gohel MC, Mehta PR, Dave PK, Bariya NH. More relevant dissolution method for evaluation of FDDS, Dissolution Technologies. 2005, 22-5. 